\title{
Water Price Calculations in Concept of Environmental Service: A Case in Cimanuk Watershed
}

\author{
Andi Setyo Pambudi ${ }^{1}$ \\ Ministry of National Development Planning/Bappenas - Indonesia
}

\begin{abstract}
Cimanuk Watershed is one of the important water sources in West Java Province. The damage that occurred in Cimanuk watershed affected the sustainability of water supply in West Java. The administrative area of Cimanuk watershed extends to 4 regencies, namely Garut Regency, Sumedang Regency, Majalengka Regency, and Indramayu Regency. The Cimanuk River itself has a length of $\pm 338 \mathrm{~km}$, which can supply water needs of 2.2 billion $\mathrm{m}^{3}$ every year with the main utilization for irrigation in agricultural areas. Forest areas in the upper Cimanuk watershed affect the continuity of the hydrological, erosion and sedimentation process. Changes in the upstream area in terms of land use and forest exploitation that do not consider environmental aspects can damage the entire watershed ecosystem, causing fluctuations in water flow, sediment transport, and material dissolved in the water flow system. Given the reciprocal relationship in the concept of watershed management, the implementation of the Payment Environmental Services or PES mechanism is important, where water is one of the components that deserve be a consideration. The economic valuation of water quantified as water prices is also a fundamental reason for the importance of PES studies. Water prices based on scientific calculations, both qualitative and quantitative, determine the "feasibility value" that will be given from the downstream community upstream as conservation actors to support the concept of fair environmental services. Quantitative analysis is carried out in the form of valuations involving several methods, namely the Contingent Valuation Method, Value of Marginal Product Water, and Full Cost Pricing. The price of water can be used as an indicator of the cost of forest environmental services as a water provider as well as improving market mechanisms. This paper concludes the mechanism of payment for environmental services (PES) through water pricing policies can be an alternative source of funding to improve the condition of a watershed.
\end{abstract}

Keywords: Water Prices, Watershed Management, Environmental Services, Forests

\footnotetext{
${ }^{1}$ Andi Setyo Pambudi is the Deputy Director for Monitoring, Evaluating and Controlling Regional Development Area IV, Ministry of National Development Planning/Bappenas. Email: andi.pambudi@bappenas.go.id
} 
Andi Setyo Pambudi

\section{Water Price Calculations in Concept of Environmental Service: A Case in Cimanuk Watershed}

Andi Setyo Pambudi

\section{Introduction}

Management of Watersheds is closely related to ecosystem approaches and water regulation (Euler et al., 2018; Bonell and Bruijnzeel, 2005). The balance of water regulation can be affected by damage to the watershed, especially due to mismanagement in the upstream part of the watershed, such as the addition of cultivated and residential areas (Bellfield et al., 2015; Kindu et al., 2017; Euler et al., 2018). Many studies have been carried out regarding the impact of human activities on the upstream of a watershed on environmental factors (Li, et al., 2018). In developing countries such as Indonesia and other Southeast Asians, watershed management still faces the problem of lack of integration between sectors, between agencies, and between regions so that water regulation becomes disrupted (Atapattu and Kodituwakku, 2009). Community participation, both upstream and downstream of the watershed, is also considered not optimal therefore environmental sustainability in the watershed area is increasingly alarming (Asdak, 2006).

Forest areas upstream of a watershed function to maintain the continuity of the hydrological process, prevent erosion, and sedimentation (Asdak, 2010; Agus et al., 2004). Changes in the upstream area in terms of land use and forest exploitation that do not consider environmental aspects can damage the entire watershed ecosystem which ultimately influences fluctuations in water flow, sediment transport, and dissolved material in the water flow system (Azadi et al., 2018; Markandya et al . 1992). Water availability is highly dependent on rainfall in the watershed area, water absorption area, and the ability of the watershed to hold water so that it does not immediately run off (Bonell and Bruijnzeel, 2005). Pressure on protected areas of water sources and their impacts shows that there is a role for society in the environment (Cumming, 2016; Watson et al., 2014). The ability of watersheds to hold water also depends on the vegetation and slope of the land so that loss of vegetation cover in water catchment areas and in protected areas will disrupt water supply from upstream to downstream (Agus et al., 2004).

Based on various experiences and cases of watershed management both inside and outside the country such as the Rhine and the Mekong River, the main problems faced are often related to the problems of cooperation, participation and agreement of all stakeholders who utilize watershed areas for goods and services industries (Atapattu and Kodituwakku 2009; Bonell and Bruijnzeel 2005; Agus et al., 2004). Stakeholders, in this case, can be individuals, groups of individuals (people), formal / non-formal organizations/institutions, as well as government and private institutions. In Indonesia, Cimanuk watershed is one of the important water sources in West Java Province. The damage that occurred in Cimanuk watershed affected the sustainability of water supply in West Java. The administrative area of Cimanuk watershed extends to 4 regencies, namely Garut Regency, Sumedang Regency, Majalengka Regency, and Indramayu Regency. The Cimanuk River itself has a length of $\pm 338 \mathrm{~km}$ which can supply water needs of 2.2 billion $\mathrm{m}^{3}$ every year with the main utilization for irrigation in agricultural areas (Rustiana et al., 2017; Pasandaran and Rosegrant 1999). Forest areas and their changes in the upper Cimanuk watershed affect the sustainability of overall water regulation in the watershed (Widiyanto and Hani, 2018). The concept of sustainable development is 
important for the sustainability of water resources management planning because it implies environmental boundaries determined by social organizations, the ability of the biosphere to accommodate human activities, and technology Cimanuk watershed concept as an ecosystem has not yet linked the mechanism of environmental services between upstream and downstream (Rustiana et al. 2017; Corn 1993). Water scarcity due to damage to watershed ecosystems has the potential to cause conflicts both from an economic and social perspective because of conflicts of interest between users. Ratnaningsih (2007) states that until now, water scarcity does not limit the pattern of water usage because of the prevailing understanding in the community that water is a public good where one of its properties is that it cannot be excluded (non-excludable). The implementation of a mechanism to pay for an environmental service for watershed management has not been done much (Pattanayak, 2004). Ideally, the application of these payments can be used to simultaneously assess the causes of forest and land damage in the upper watershed, as well as the actors of pollution and environmental damage in one watershed (Ratnaningsih 2007; Asdak 2004).

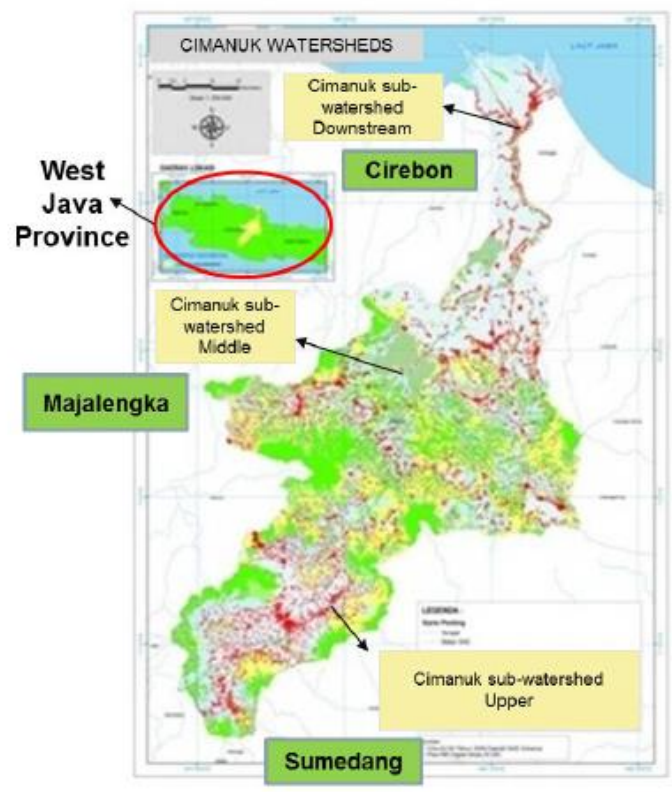

Figure 1. Cimanuk Watershed, West Java

Source: Rustiana et al., 2017

Given their mutual relations in the concept of watershed management, the implementation of a mechanism to pay environmental services or Payment Environmental Services (PES) is important applied, where the water becomes one of its components. The economic valuation of water quantified as water prices is also a fundamental reason for the importance of PES studies. Water prices based on scientific calculations, both qualitative and quantitative, need to be taken into account to determine the "feasibility value" that will be given from downstream to upstream communities as conservation actors to support the concept of environmental services of fair. The question that arises later, what is the reasonable price of water in the concept of environmental services in Cimanuk watershed? How are policy recommendations needed based on the calculation of water prices (PES)? 


\section{Method}

Integration of upstream-downstream with a mutually supportive role is a keyword in managing a more equitable and watershed sustainable, with attention to the balance between the economy, social, and environment (Rogers et al. 2008; Asdak 2010). Various rehabilitation activities, forest and land conservation, and land-use arrangements determine the continuity of quality and quantity of water in Cimanuk watershed. The problem of water availability can be a correction of the environmental services market if the policy approach taken is related to the price of water itself (Common and Stagl 2005; Panayotou 1998). Water regulation will be achieved optimally if the allocation of funds from environmental services is used for environmental management which is the root cause of the damage to the watershed, namely in the upstream area of Cimanuk watershed.

This research method is carried out through a literature study qualitatively and quantitatively by analyzing problems and calculating the price of water in Cimanuk watershed in the concept of environmental services (PES). Qualitative analysis is specifically carried out to analyze the Concept of Environmental Services in Cimanuk watershed. Quantitative analysis is carried out in the form of valuations involving several methods, namely the Contingent Valuation Method, Value of Marginal Product water, and Full Cost Pricing (Ratnaningsih 2007; Soesastro and Atje 2005; Chandler and Suyanto 2004; Pattanayak 2004; Panayotou 1998; Ratnaningsih 1997; Ratnaningsih 1997; Markandya et al. 1992, Nicholson 1992)

a) Contingent Valuation Method

There are two ways to provide environmental service value, namely through efforts to directly ask the community in the upstream and downstream watershed about the value or price of water that is ideal for a particular environmental service. This method is often termed the Contingent Valuation Method or CVM). This method positions environmental services equivalent to goods and services available on the market. The method of calculating willingness to pay or receive compensation (Willingness to Pay or more simply termed WTP and Willingness to Accept or more simply termed WTA) can be done to determine the variation in compensation expected by the community upstream and downstream of the watershed.

b) Value of Marginal Product from water

In the process of producing goods and services, needed various inputs to produce a product. Water is one of the factors input that is widely used in the production process but is rarely counted as a factor cost of production as well as other input factors. The method of calculating the Value of Marginal Product (VMP) from water can be used to determine the value of water as an input factor in the production process. To calculate the price of water, it is necessary to calculate the value of the elasticity coefficient for water $(\tau)$ used in the production process. The simple assumption used in this concept is that each company will try to maximize profit or profit so that it can be said that the price of the factor input (water price) is equal to the marginal product value of water itself (VMPWater), or can be formulated as follows (Ratnaningsih, 1997):

$$
\begin{aligned}
& \mathrm{H}_{\mathrm{A}}=\mathrm{VMP}_{\mathrm{A}} \\
& \text { Or because of } \mathrm{VMP}_{\mathrm{A}}=\mathrm{MP}_{\mathrm{A}} \times \mathrm{P}_{\mathrm{Q}} \text {, so } \\
& \mathrm{H}_{\mathrm{A}}=\mathrm{MP}_{\mathrm{A}} \cdot \mathrm{P}_{\mathrm{Q}}
\end{aligned}
$$




$$
\begin{array}{ll}
\mathrm{MP}_{\mathrm{A}}=\tau . & \mathrm{Q} \\
\text { where: } & \mathrm{A}
\end{array}=\left[\begin{array}{ccc}
\underline{\Delta Q} & \underline{\mathrm{A}} & \mathrm{Q} \\
\Delta \mathrm{A} & \mathrm{Q} & \mathrm{A}
\end{array}\right]
$$

$\mathrm{VMP}_{\mathrm{A}}=$ Value of Marginal Product from water

$\mathrm{MP}_{\mathrm{A}}=$ Marginal Product from water or production increase due to increase 1 unit $\left(\mathrm{m}^{3}\right)$ water.

$\mathrm{t}=$ Regression coefficient of water variable or water elasticity

$\mathrm{Q}=$ rice production level (ton)

$\mathrm{A}=$ water use rate $\left(\mathrm{m}^{3}\right)$

$\mathrm{P}_{\mathrm{Q}}=$ price of rice $(\mathrm{Rp})$

$\mathrm{H}_{\mathrm{A}}=$ price of water $\left(\mathrm{Rp} / \mathrm{m}^{3}\right)$

c) To get the estimated price of water in the agricultural sector, then $\mathrm{MP}_{\mathrm{A}}$ must be multiplied by the price-output of the average price of rice (PQ). To get the estimated price of water in the agricultural sector, then MPA must be multiplied by the output of the average price of rice (PQ).

d) Full Cost Pricing

e) The basis for determining full cost pricing can be seen in Figure 2 (Panayotou, 1998) which explains that market failure in assessing the cost of externalities causes Marginal Environmental Cost (MEC) to be zero, thus shifting point A to point $\mathrm{B}$ because social costs due to environmental damage are not taken into account. Institutional failure, especially in regulating ownership rights, causes unlimited use of water as public goods. This has led to a lack of public interest in conserving water resources where the use of water tends to be exploitative in current use. Opportunity cost (Marginal User Cost, MUC) of forest resources as water management is not taken into account, so deplisi costs are zero and will shift point $\mathrm{B}$ to point $\mathrm{C}$. Water price subsidies provided by the government due to social functions and public goods attached to water has caused water price distortion. This causes the marginal cost of production (Production Marginal Cost, MPC) is lower than the social opportunity cost (Social Opportunity Cost $=\mathrm{SOC}$ ) causing excessive usage and shift the point $\mathrm{C}$ to point $\mathrm{D}$.

The above understanding may be formulated in the following equation:

$\mathrm{P}=\mathrm{MSOC}$

$$
\begin{aligned}
& \mathrm{MSCO}=\mathrm{MPC}+\mathrm{MUC}+\mathrm{MEC} \\
& \mathrm{P}=\mathrm{MPC}+\mathrm{MUC}+\mathrm{MEC}
\end{aligned}
$$

The demand curve (D) in Figure 2 illustrates the marginal social benefit (Marginal Social Benefit, MSB) of the various levels of usage of outputs (water). Price subsidies provided by the government cause a high level of water use, namely when the price of Po and usage is as high as Qo. The application of price policies through the approach full cost pricing reduces water use from $Q 0$ to $Q^{*}$ and water prices increase from $\mathrm{Po}$ to $\mathrm{P} *$. Economic valuation through approach is full cost pricing able to include social and environmental costs that have never been calculated before and can provide valid information about scarcity of water resources 
indicated by high prices in the event of water scarcity or vice versa at low prices when occurs surplus of water.
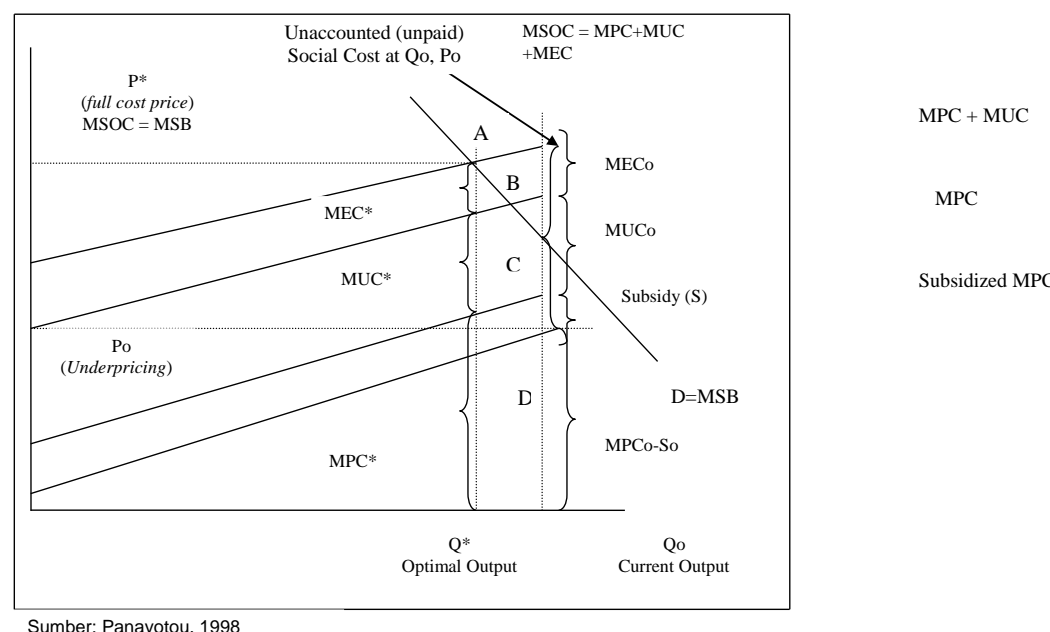

Figure 2. Method Full Cost Pricing

Source: Panayotou, 1998

\section{Results and Discussion}

In general, payments for forest environmental services are carried out through a mechanism approach. The value of water prices is expected to be one way to overcome the limited sources of funds for the rehabilitation and conservation of forests and land in the upper watershed. Theoretically, the theory of payments for environmental services with approach market-based instruments to water pricing as a commodity that includes the value of externalities of land use and forest environmental services is expected to strengthen the basis for determining the value of payments for environmental services. Practically, the mechanism of the market for forest environmental services through the application of the concept of payment of water prices is expected to change the community's perspective on forest and water environmental services as public goods that have high social functions and become high-value commodities to encourage sustainable environmental management.

High discharge fluctuations are one indicator of the high level of damage to watersheds. Ideally, the surface of the watershed can absorb water maximally so that the rainwater that falls will seep into the soil and can fill water sources especially for the supply of water reserves in the dry season. Water stored in the soil can be flowed to meet the water needs of all activities. The high level of land conversion and forest destruction in the upper watershed disrupts the hydrological cycle which results in the reduction of rainwater that seeps into the ground so that most of it becomes run-off. It can be seen that the watershed's ability to absorb and store water has decreased. Deforestation and land use that is not under conservation rules cause imbalances in the hydrological cycle and disturbances in water availability. Nicholson (1992) states that so far the environment has been seen as common property resources as free goods that have no value. The not yet popular value of an 
environmental factor in the economic system has resulted in the absence of excessive control mechanisms for controlling natural use, particularly related to the utilization of production factors. Solving environmental problems must be done by giving a sign that the scarcity of natural and environmental resources has begun to occur and the control mechanism must be implemented. So far in Indonesia water is still considered by some people as not an economic value because of the abundant supply. Meanwhile, in the concept of PES, the value of water is one of the key factors that must be known because it can simply describe the value of PES itself. The stages of calculating water values for environmental services in Cimanuk watershed are carried out based on calculation formulas as stated earlier in the method chapter of this paper.

\section{a) Willingness to Accept (WTA) rice farmers in the downstream Cimanuk Watershed}

Users of water downstream of Cimanuk watershed are asked to provide answers to questions about the causes of water problems experienced by respondents. Water users, in this case, are farmers (respondents 20 people) in Karangmulya Village, Purwajaya Village, and Lohbener District, Indramayu Regency. The interesting thing about this interview is that the answers given indicate an understanding of the concept of conservation. The interview continued with questions about the willingness of respondents to pay a certain amount of funds for rehabilitation and forest conservation in the upper watershed so that water availability is getting better and more sustainable. Based on the survey results, on average, sample farmers who use water in the lower watershed are on average willing to pay Rp. 265,220 per person/harvest or Rp. 96 per $\mathrm{m}^{3}$ of water. This was motivated by a condition that if a crop failed, the average farmer would suffer a loss of IDR 2,333,700 per person/harvest. In the PES concept offered, farmers feel that they benefit from paying for water and there is no drought worth IDR 1,968,480 per person/harvest.

\section{b) Willingness to Pay (WTP) of farmers in Cimanuk watershed}

In addition to looking at the willingness to pay from farmers in Cimanuk watershed, questions about willingness to receive compensation were asked of farmers (respondents 20 people) in the upper watershed. When respondents are advised to reforest their area and replace their current livelihood (from forest land use) with activities agroforestry, there are two interesting answers to be analyzed more deeply. Based on the answers obtained, it is known that overall, the average compensation desired by respondents in the upper reaches of Garut Regency is Rp. 878,804 , - per month or Rp. 555, - per $\mathrm{m}^{3}$ of water used. This figure is around $13 \%$ higher than the average income of the current respondents, which is Rp. 778,370, per month. Based on the calculation results it appears that the amount of willingness to pay or PAPs by respondents in the lower Cimanuk watershed is lower at Rp 265,217 per harvest or Rp 530,434 per year compared to the amount of compensation or WTA expected by respondents in the upper Cimanuk watershed of Rp 878,804 per month or Rp. 10,545,648, - per year. This happens because the willingness to pay is limited by the income level of the respondent while the willingness to accept compensation is not limited but uses the average income as a minimum payment benchmark that is expected to be received instead of current income. 


\section{c) Value of Marginal Product from water}

The calculation results using data from 3 sample locations, namely Lohbener District, Purwajaya Village, and Karangmulya Village obtained values Marginal Product from the water of 0.253 for downstream rice and 0.291 for upstream rice. To get an estimate of the price of water, MPWater must be multiplied by the price, output average namely the price of rice (PQ) wherein this study it was found that the average price of rice in the downstream in 2007 was IDR 2,245 per kg. water is:

$$
\begin{aligned}
& \mathrm{MP}_{\text {Water }} \times \mathrm{P}_{\mathrm{Q}} \quad=\mathrm{P}_{\text {water }} \\
& 0,253 \times \operatorname{Rp} 2.245,-=\mathbf{R p} 653,29 \text { per } \mathbf{m}^{3} \text { (Rounding to } \mathbf{R p ~ 6 5 3 , - )}
\end{aligned}
$$

To obtain the value of water for upstream rice plants, MPWater must be multiplied by the price-output of rice (PQ) wherein this study it was found that the average price of upstream rice was IDR 1,980 per $\mathrm{kg}$, then the price of water was:

$$
\begin{aligned}
& \mathrm{MP}_{\text {Water }} \times \mathrm{P}_{\mathrm{Q}} \quad=\mathrm{MC}_{\text {Water }} \\
& 0,2196 \times \mathrm{Rp} 1.980,-=\mathbf{R p} \text { 434,84 per } \mathbf{m}^{3} \text { (Rounding Rp 435,-) }
\end{aligned}
$$

\section{d) Methods full cost pricing}

Method full cost pricing using a water supply value calculation approach that includes physical infrastructure waterways, as well as social and environmental costs incurred to create water. To be able to calculate the value or price of water with this method, it requires at least 3 (three) financing components to be known, namely:

- Marginal Production Cost (MPC)

The value of physical water procurement can be calculated by summing all costs of investment, operation, and maintenance, rehabilitation drains, as well as water management costs in one component cost. The costs used to calculate the total cost of production is still limited to financial costs or explicit costs, that is the fees actually paid. While economic costs or implicit costs have not been taken into account, such as the loss of farmers' opportunities to cultivate land because their fields are used to build irrigation facilities, the loss of employment opportunities due to the ongoing construction of irrigation facilities, and so on. Thus the total physical cost of procuring water used in this study is as follows (Table 1):

Table 1. Physical Cost of Water Procurement in 2018

\begin{tabular}{|l|r|}
\hline \multicolumn{1}{|c|}{ Information } & \multicolumn{1}{c|}{ Cost (Rp/ha) } \\
\hline New Investment & $35.000 .000,-$ \\
\hline Operation and maintenance & $190.000,-$ \\
\hline Rehabilitation & $8.100 .000,-$ \\
\hline Sub Total & $43.290 .000,-$ \\
\hline Management fee (10\% from total) & $4.329 .000,-$ \\
\hline Total & $47.619 .000,-$ \\
\hline
\end{tabular}

Source: Analysis Results 
Given that the costs listed in Table 1 are costs in 2018, while the irrigation channel data in Cimanuk watershed is 2015, it is necessary to calculate it using a discount factor to reflect the amount of the physical cost of water procurement in 2015. The discount factor used is $7 \%$ according to the average inflation rate per year ( Soesastro and Atje, 2005) for 3 years. Thus the physical cost of procuring water per hectare for technical channels in 2015 is:

$$
\begin{aligned}
& \mathrm{P}_{\mathrm{o}}=\mathrm{P}_{\mathrm{t}} /(1+\mathrm{r})^{\mathrm{t}} \\
& \mathrm{P}_{\mathrm{o}}=\underline{47.619 .000}=\mathbf{R p} \text { 38.879.653,- } \\
& (1+0,07)^{3}
\end{aligned}
$$

Table 2. MPC Water Supply Value in Cimanuk Watershed in 2015 Type of channel

\begin{tabular}{|l|r|r|r|r|}
\hline \multicolumn{1}{|c|}{$\begin{array}{c}\text { Type } \\
\text { Channel }\end{array}$} & $\begin{array}{c}\text { Total } \\
\text { Water } \\
\left(\text { Juta }^{3}\right)\end{array}$ & $\begin{array}{c}\text { Irrigation } \\
\text { Area } \\
(\mathrm{Ha})\end{array}$ & $\begin{array}{c}\text { Total Cost } \\
\text { Water } \\
\text { (Rp. Juta) }\end{array}$ & \multicolumn{1}{c|}{$\begin{array}{c}\text { MPC } \\
\text { Water }\left(\mathrm{Rp} / \mathrm{m}^{3}\right)\end{array}$} \\
\hline Technical & $1.824,80$ & 96.002 & $3.731 .597,7$ & $2.044,93$ \\
\hline $\begin{array}{l}1 / 2 \\
\text { Technical }\end{array}$ & 558,87 & 29.402 & $715.350,66$ & $1.279,99$ \\
\hline Simple & 737,53 & 38.801 & $541.273,95$ & 733,90 \\
\hline
\end{tabular}

Source: Analysis Results

- Marginal User Cost (MUC)

To calculate the total value of water supply, besides physical costs the provision of water must also be calculated for the current costs lost due to the use of natural resources. To calculate the amount of MUC costs, the approach used is to use the area of critical land in Cimanuk watershed as a proxy for current forest use, thereby reducing forest availability and function in the future. With the conversion of forest areas and logging, the function of forests as a water system is also lost, resulting in a loss of water availability in the future.

Marginal User Cost for this case is calculated by using the cost of rehabilitation of critical land in Cimanuk watershed (10,450 ha) of Rp $177,107.86$ million. The assumption used is that the area of critical land will disrupt the availability of water in the irrigation canal. The calculation is done by dividing the critical land area from the total area of the forest, then the results are multiplied by the amount of water available in the irrigation channel.

(L. Critical Land $\div$ L Forest Land) x Total Water $=$ Total Lost Water

$(131,348$ ha $\div 308,503$ ha $)$ x 3,1 19.89 Million $\mathrm{m}^{3}=1,325.95$ million $\mathrm{m}^{3}$

By dividing the cost of rehabilitating critical land with the amount 
of water lost than obtained water MUC value that is equal to:

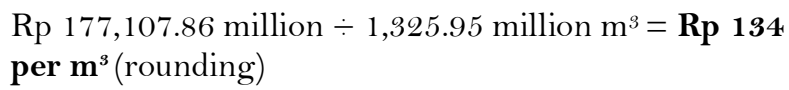

- Marginal Environmental Cost (MEC)

The MEC value is used to show the value of forest environmental services as water providers. To obtain the MEC value, the method of benefit transfer is used, which uses the results of calculations performed by other researchers. The study conducted by the Scottish government concluded that based on the results of the component analysis carried out, forest damage had an impact on the occurrence of floods and erosion in the area around the watershed. The results of these calculations can be used as the basis for calculating the cost of the impact of forest damage on flooding and erosion in the agricultural sector in Cimanuk watershed by multiplying the value obtained by the value of rupiah (US $\$ 1=14,000$ IDR) and multiplying it again by $9.6 \%$ to indicate the existence of differences in purchasing power (purchasing power parity, PPP) (Ratnaningsih, 2007).

Table 3. Calculation of the Impact Cost of Forest Damage to Floods and Erosion in Cimanuk watershed

\begin{tabular}{|l|r|}
\hline Criteria & Cost(Rp/Ha) \\
\hline Agricultural sector losses & 555.448 \\
Erosion damage & 4.936 .378 \\
Cleaning cost & 16.908 .998 \\
Household Losses & 115.154 \\
Income Losses & 160.877 \\
\hline \multicolumn{1}{|c|}{ Total } & 22.676 .855 \\
\hline
\end{tabular}

Source: Analysis Results

The total cost of the loss is divided by the total availability of water in the irrigation to produce value MEC namely:

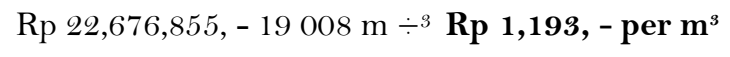

By knowing the value MPC + MEC + MUC then proceeds prices water can be calculated based on the method full cost pricing as shown in Table 4 below:

Table 4. Water Prices Based on Calculation Full Cost Pricing $\left(\mathrm{Rp} . / \mathrm{m}^{3}\right)$

\begin{tabular}{|l|r|r|r|r|}
\hline Irrigation & MPC & MUC & MEC & Total \\
\hline Technical & 2.045 & 134 & 1.193 & 3.372 \\
\hline $1 / 2$ Technical & 1.280 & 134 & 1.193 & 2.607 \\
\hline Simple & 734 & 134 & 1.193 & 2.061 \\
\hline
\end{tabular}

Source: Analysis Results 


\section{Conclusion}

Damage to watershed ecosystems occurs partly due to market failure in assessing watershed ecosystem services in the economic system that use the watershed area. The price of water can be used as an indicator of the cost of forest environmental services as a provider of water as well as to improve market mechanisms. Calculation of water prices with a full cost pricing approach can be used to show the actual value of water procurement because it involves the physical costs of water supply (MPC), social opportunity costs lost due to natural resource use (MUC), and costs of forest services to prevent environmental damage (MEC). The MUC and MEC values are environmental costs that must be returned to nature to maintain the ecological functions of the environment. The full cost pricing method can also be used as the basis for preparing a water price calculation model that is adjustable to watershed conditions and water availability. When the condition of the watershed is well organized and the water supply exceeds the number of requests, then the water price will be lower than when the watershed is damaged and the water supply is smaller than the amount of water demand.

The calculation of water prices using the Value of Marginal Product (VMP) also conducted to illustrate that the value of water as a factor input in a production process must be calculated as well as other factors input. Besides, knowing the coefficient of elasticity of water to the amount of rice production can be used to assess the productivity of water against rice production. Another approach used to calculate water prices is the method of Contingent Valuation through the willingness to pay for environmental services for water user farmers (WTP).

To be able to implement the PES mechanism through the mechanism of paying the value or price of water, a control and transparency function is needed. Funds originating from payment of water prices must be allocated by their functions, namely physical water procurement (MPC), as well as for payment of environmental services (MUC and MEC) for land rehabilitation and conservation.

The mechanism for paying for environmental services (PES) through water pricing policies can serve as an alternative source of funding to improve the condition of a watershed. The perspective that prioritizes water and environmental services as public goods that have high social functions is time to change. Water is no longer a public good but as a commodity that has important value due to the existence of forest environmental services. The price of water must be set as high as the value of full-cost pricing because the value reflects the actual cost of water supply which includes the cost of environmental services. But the price of water must at least be equal to the marginal production value. Whereas WTP is the lowest water price that can be applied because it is in accordance with the willingness and ability of the community to pay for environmental services. The difference in value between PAPs and VMP air and full cost pricing can be closed by cross-subsidy between sectors of water users or government funds. Funds originating from payments for environmental services must be used for land conservation and rehabilitation that involves the community to participate in its implementation.

\section{References}

Agus, Fahmudin, Meine van Noordwijk, and Rahayu S. (2004). The hydrological impact of forests, agroforestry, and dryland agriculture as a basis for providing rewards to producers of environmental services in Indonesia. Workshop Proceedings in Padang / Singkarak, West Sumatra, Indonesia, 
25-28 February 2004. World Agroforestry Center (ICRAF) - SEA, Bogor, Indonesia.

Atapattu, Sithara S., and Kodituwakku, C. Dekshika. (2009). Agriculture in South Asia and Its Implications on Downstream Health and Sustainability. Journal of Agriculture Water Management. Publisher: Elsevier. DOI : 10.1016/j.agwat.2008.09.028

Asdak, Chay. (2010). Hydrology and Management of Watersheds. Fifth Edition (Revised). Yogyakarta: Gadjah Mada University Press.

Asdak, Chay. (2006). Community-Based Watershed Management in Administrative Border Areas. Paper, delivered at the coordination meeting on the development of border area cooperation in the forestry sector. Bandung.

Azadi, Hossein, Parisa Keramati, Fatemeh Taheri, Parisa Rafiaani, Dereje Teklemariam, Kindeya Gebrehiwot, Gholamhossein Hosseininia, Steven Van Passel, Philippe Lebailly and Frank Witlox. (2018). Agricultural Land Conversion: Reviewing Drought Impacts and Coping Strategies. International Journal of Disaster Risk Reduction, https://doi.org/10.1016/j.ijdrr.2018.05.003

Bellfield, Helen et al. (2016). How Can Indonesia Achieve Water, Energy and Food Security?. WCS and Global Canopy Programme. Indonesia

Bonell, Mike, and Bruijnzeel, L.A. (2005). Forest, Water, and People in the Humid Tropics: Past, Present, and Future Hydrological Research for Integrated Land and Water Management. United Kingdom: Cambridge University Press.

Chandler, Fiona J.C. dan Suyanto. (2004). Recognizing and rewarding the provision of watershed services. World Agroforestry Centre (ICRAF Southeast Asia).

Common, Michael dan Sigrid Stagl. (2005). Ecological Economics: An Introduction. New York: Cambridge University Press.

Corn, M. L.(1993). Ecosystems, Biomass, and Watersheds: Definitions and Use. Washington: National Council for Science and the Environment

Cumming, Graeme S.(2016). The Relevance and Resilience Of Protected Areas in the Anthropocene. Anthropocene https://doi.org/10.1016/j.ancene.2016.03.003

Euler, Johannes, and Sonja Heldt. (2018). Science of the Total Environment From Information to Participation and Self-Organization: Visions for European River Basin Management. Journal Science of the Total Environment. https:/?doi.org/10.1016/j.scitotenv.2017.11.072

Markandya, Anil, dan Julie Richardson. (1992). Environmental Economics. Earthscan Publication, London, page. 92-100.

Nicholson, Walter. (1992). Microeconomic Theory, Basic Principles, and Extensions. The Dryden Press International Edition, Fifth Edition, USA.

Panayotou, Theodore. (1998). Instruments of change, motivating and financing sustainable development. UNEP-Earthscan, London.

Pasandaran, Effendi, and M.W. Rosegrant. (1999). Irrigation investment in Indonesia: trend and determinants, dalam I. Wayan Rusastra, etc. Editor. The dynamics of agricultural social economic and institutional innovation. Center for Agriculture Socio-Economic Research, Agricultural Research and Development Agency, Ministry of Agriculture, page 56-71.

Pattanayak, S.K. (2004). Valuing Watershed Services: Concepts and Empirics from South East Asia. Agriculture, Ecosystem, and Environment. DOI:10.1016/j.agee.2004.01.016 
Ratnaningsih, Maria. (1997). Determination of Pollution Charge and its Impact on the Textile Industry in Indonesia. Thammasat Economic Journal 14, page. $20-50$

Ratnaningsih, Maria. (2007). Indonesia Country Environmental Analysis, Economic Cost and Degradation. The World Bank, Jakarta.

Rustiana,Shailla, Budi Nurani Ruchjana, Atje Setiawan Abdullah, Eddy Hermawan, Sinta Berliana Sipayung, I Gede Nyoman Mindra Jaya, and Krismianto. (2017). Rainfall Prediction of Cimanuk Watershed Regions with Canonical Correlation Analysis (CCA). IOP Conf. Series: Journal of Physics: Conf. Series 893 (2017) 012021. doi :10.1088/1742-6596/893/1/012021

Soesastro, Hadi dan Raymond Atje (2005). Survey of Recent Developments, Bulletin of Indonesian Economic Studies 41 (1): 5-34. https://doi.org/10.1080/00074910500072641

Watson, James E.M, Dudley, N., Segan, D.B., Hockings, M. (2014). The Performance and Potential of Protected Areas. Nature 515(7525):67$73 \cdot$ November 2014. DOI: 10.1038/nature 13947

Widiyanto, Ary dan Aditya Hani. (2018). Pattern and evaluation of land use in Cinangka Buffer Zone, Upper Cimanuk Sub Watershed. Journal of Watershed Management Research. DOI https://doi.org/10.20886/jppdas.2018.2.1.61-72 